\title{
Two Reports of Interest
}

\section{Sage Grouse Initiative Tracking Success 2013 Report}

In late January, the Sage Grouse Initiative (SGI) partners announced the release of Sage Grouse Initiative: Tracking Success, ${ }^{1}$ a highly visual 44-page report that reveals six secret ingredients of a paradigm shift for bringing back wildlife in trouble without listing them under the Endangered Species Act. The report can be accessed on the SGI website. ${ }^{i}$

The SGI is a targeted, science-based landscape approach, launched in 2010 by the US Department of Agriculture's Natural Resources Conservation Service (NRCS) in 11 western states, to recover sage grouse and other wildlife by working with ranchers to improve and conserve their lands. It uses win-win solutions and partnerships to leverage money for conservation of sage grouse habitat and to keep the sage grouse off the endangered species list. The SGI is an example of how NRCS is taking a voluntary approach that benefits both agriculture and sage grousealong with a suite of other wildlife species-instead of regulatory approaches.

According to the Tracking Success report, the first ingredient of success is the shared vision - what's good for rangelands is good for grouse - of the partners involved, including government agencies, nonprofits, for profits, conservation groups, and ranchers. The following is from the report:

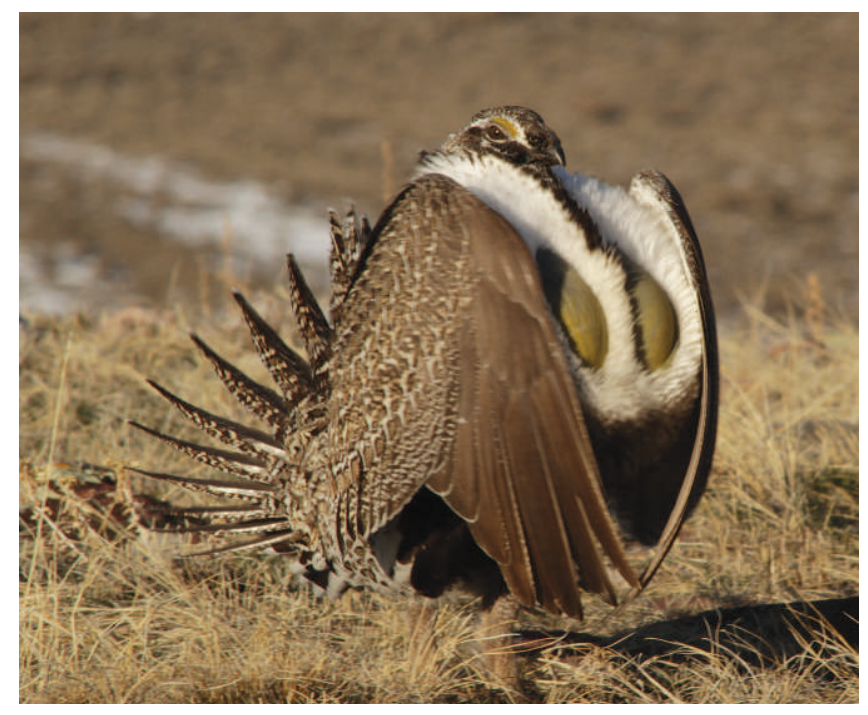

Displaying male sage grouse. Photo by Jeremy R. Roberts, Conservation Media.

The speed of success matches the scale: $700+$ ranchers enrolled; investments of $\$ 145$ million generate $\$ 70$ million in matching contributions; conservation easements reduce sodbusting and subdivision threat on 240,000+ acres; new grazing systems increase biding cover for nesting birds on 2+million acres; removal of invading conifers restores historic sagebrush on 200,000 acres, and marking or removing 500+ miles of high-risk fences prevent bird collisions (p. 6) ${ }^{1}$.

The other five secret ingredients include being strategic - directing resources where conservation returns are highest; accountability — using scientific methods to track sage grouse and

' Download the report at http://sagegrouseinitiative.com/content/2013-sage-grouse-initiative-tracking-successreport-released. 
their habitat to evaluate and improve program effectiveness; leverage - multiplying investments through partner contributions and replicating success throughout sage grouse strongholds; certainty - letting participating ranchers who keep up conservation practices for sage grouse know they won't face additional regulations; and trust and credibility - building personal relationships with scientists, ranchers, conservationists, and others committed to the success of the program.

The report also highlights success stories from each of the 11 states. For example, in Sublette County, Wyoming, an impressive land agreement conserved nearly 19,000 acres of historical agricultural land, critical habitat for sage grouse and other wildlife, and iconic view sheds. The report concludes with the SGI's Vision for the Future, showcasing education programs to engage future generations in rangeland and sage grouse conservation.

For more information on the Sage Grouse Initiative, check out their web site ${ }^{\mathrm{ii}}$ or contact Tim Griffiths, NRCS Sage Grouse Initiative Coordinator, Bozeman, MT 59715, USA, (406) 587-6812, Info@sagegrouseinitiative.com.

\section{Third National Climate Assessment}

Earlier this year, the draft Third National Climate Assessment $^{2}$ (NCA) was released by the US Global Change Research Program (USGCRP) under the auspices of the Global Change Research Act of 1990. The GCRA requires that every 4 years, a report that integrates, evaluates, and interprets the findings of the USGCRP be made to the President and Congress. The report, which can be downloaded from the USGCRP website, ${ }^{\text {iii }}$ also analyzes the effects of global change on the natural environment, agriculture, energy production and use, land and water resources, transportation, human health and welfare, human social systems, and biological diversity, as well as current trends in global change- both human-induced and natural-and projects major trends for the subsequent 25 to 100 years.

The Third NCA was overseen by a 60 -person Federal Advisory Committee (the National Climate Assessment and Development Advisory Committee, NCADAC), established under the Department of Commerce in December 2010 and supported through the National Oceanic and Atmospheric Administration. Its members are diverse in background, expertise, geography, and sector of employment. The Committee served to oversee the NCA activities, engaging more than 240 authors in the creation of the third report.

The goal of the NCA is to communicate our understanding of climate change science and impacts in the United States. It informs the nation about observed changes, current status, and anticipated trends for the future. The development of the report integrated scientific information from many sources and sectors to highlight key findings and knowledge gaps. The NCA process is establishing consistent methods

\footnotetext{
ii http://www.sagegrouseinitiative.com

iii Download the National Climate Assessment report at http://ncadac. globalchange.gov.
}

for evaluating climate impacts, collecting diverse stakeholder voices, and providing input to science priorities. The findings from the NCA can be used by citizens, communities, and businesses to create more sustainable plans for their future.

The NCA studies how climate change impacts different geographic regions and sectors across the United States, including human health; land use and land cover change; agriculture; forestry; ecosystems and biodiversity; water resources; energy supply and use; transportation; urban infrastructure and vulnerability; rural Communities; biogeochemical cycles; oceans and marine resources; tribal, indigenous, and native lands and resources; and coastal Zones; as well as adaptation and mitigation and intersections among these topics.

The 2013 NCA will set the stage for more comprehensive assessments in the future. It will differ from previous US climate assessments by: 1) being an ongoing effort, rather than a periodic report-writing activity; 2) evaluating the nation's progress in adaptation and mitigation; 3 ) building long-term partnerships with entities in both the public and the private sectors; 4) identifying national indicators of change within regions and sectors, and establishing consistent and ongoing methods for evaluating them; 5) including new methods for documenting climate related risks and opportunities; and 6) providing web-based information that supports decisionmaking processes within and across regions and sectors of the United States.

The NCA will present a comprehensive picture of the changes in regions and sectors that occur in response to climate variability and change, including effects on public health and human well-being, the economy, infrastructure, and the environment. This information will help decision makers throughout the country design adaptation policies, help citizens prepare themselves for climate change impacts, and help everyone understand how their everyday decisions impact the climate and the environment. The report will be revised following a public comment period. The final report will then serve as the basis for on-going assessment activities.

\section{References}

1. Sage Grouse Initiative. 2013. Sage Grouse Initiative: Tracking Success. 44 p. Available at: http://static.sagegrouseinitiative.com/ sites/default/files/sgi-tracking_success-final_low_res-020613. pdf. Accessed 20 February 2013.

2. National Climate Assessment and Development Advisory Committee. 2013. Third National Climate Assessment. 1193 p. Available at: http://ncadac.globalchange.gov. Accessed 20 February 2013.

Lori Hidinger, lori.bidinger@asu.edu.

Rangelands 35(2):22-23

doi: 10.2111/RANGELANDS-D-13-00005.1

(C) 2013 The Society for Range Management 